\title{
Unraveling the mysteries of serum albumin-more than just a serum protein
}

\author{
Angelica M. Merlot*, Danuta S. Kalinowski and Des R. Richardson* \\ Molecular Pharmacology and Pathology Program, Department of Pathology, Faculty of Medicine, Bosch Institute, The University of Sydney, Sydney, \\ NSW, Australia
}

\section{Edited by:}

Ovidiu Constantin Baltatu, University

Camilo Castelo Branco, Brazil

\section{Reviewed by:}

Bruno Vogt, Inselspital - University

of Berne, Switzerland

Ovidiu Constantin Baltatu, University

Camilo Castelo Branco, Brazil

*Correspondence:

Angelica M. Merlot and

Des R. Richardson, Molecular

Pharmacology and Pathology

Program, Department of Pathology,

Faculty of Medicine, Bosch Institute,

The University of Sydney, Blackburn

Building D06, Sydney, NSW 2006,

Australia

e-mail:amer7408@

uni.sydney.edu.au;

d.richardson@med.usyd.edu.au
Serum albumin is a multi-functional protein that is able to bind and transport numerous endogenous and exogenous compounds. The development of albumin drug carriers is gaining increasing importance in the targeted delivery of cancer therapy, particularly as a result of the market approval of the paclitaxel-loaded albumin nanoparticle, Abraxane ${ }^{\circledR}$. Considering this, there is renewed interest in isolating and characterizing albumin-binding proteins or receptors on the plasma membrane that are responsible for albumin uptake. Initially, the cellular uptake and intracellular localization of albumin was unknown due to the large confinement of the protein within the vascular and interstitial compartment of the body. Studies have since assessed the intracellular localization of albumin in order to understand the mechanisms and pathways responsible for its uptake, distribution and catabolism in multiple tissues, and this is reviewed herein.

Keywords: serum albumin, albumin-binding proteins, albumin receptors, gp60, tumors, albumin drug carriers

\section{SERUM ALBUMIN STRUCTURE}

Serum albumin is the most abundant protein in the blood plasma of all vertebrates with the concentration in human serum being $35-50 \mathrm{mg} / \mathrm{mL}$ (Peters, 1996). Human serum albumin (HSA) has a molecular mass of 66,348 $\mathrm{Da}$ and is composed of three homologous domains, numbered I, II, and III (Figure 1) (He and Carter, 1992; Peters, 1996; Sugio et al., 1999). Each domain is grouped into subdomains $\mathrm{A}$ and $\mathrm{B}$ that possess common structural motifs. The two principal regions responsible for ligand-binding to HSA are known as Sudlow's Site I and II, located in subdomain IIA and IIIA (Figure 1), respectively (Sudlow et al., 1976; Peters, 1996). Albumin is coded by a single gene, which is expressed in a co-dominant manner with both alleles being transcribed and translated (Hawkins and Dugaiczyk, 1982; Peters, 1996). The human albumin gene is located on the long arm of chromosome 4 at position q13.3.

\section{FUNCTION}

Albumin is primarily synthesized by the liver with the human liver producing $\sim 13.9$ g of HSA per day (Peters, 1996). HSA has an approximate half-life of 19 days and is degraded more effectively if it is denatured or structurally altered (Peters, 1996). Albumin has a variety of important functions and is responsible for $80 \%$ of the colloidal osmotic pressure of blood (Peters, 1996). Significantly, albumin is able to bind various endogenous molecules, including long-chain fatty acids, steroids, L-tryptophan, etc. (KraghHansen, 1981; Peters, 1996; Evans, 2002). Moreover, albumin is also involved in transporting ions in the circulation, including copper, zinc, calcium, etc. (Peters, 1996).
Additionally, this vital protein is able to bind exogenous compounds and drugs, such as warfarin, ibuprofen, chlorpromazine and naproxen, with the affinity of their binding significantly affecting their activity and half-life (Kragh-Hansen, 1981; Peters, 1996; Evans, 2002). Furthermore, albumin also acts as a toxic waste carrier, binding bilirubin, the product of heme breakdown, to deliver it to the liver for hepatic excretion (Peters, 1996). Interestingly, albumin is also believed to act as an anti-oxidant on account of its ability to: (1) protect bound substances from peroxidative damage (e.g., fatty acids and lipoproteins); and (2) bind free copper, limiting its redox activity and the production of free radicals (Peters, 1996; Evans, 2002). Lastly, albumin is a source of thiols that are avid reactive oxygen and nitrogen species scavengers (Peters, 1996; Evans, 2002).

\section{DISTRIBUTION}

Interestingly, albumin is predominately present in the extravascular space $(\sim 242 \mathrm{~g})$ rather than the intravascular space $(\sim 118 \mathrm{~g})$ (Peters, 1996; Evans, 2002). In fact, the protein is prevalent in extracellular locations such as skin, gut, muscle, other fluids (i.e., cerebrospinal, pleural, etc.) and secretions (e.g., sweat, tears and milk) (Peters, 1996). However, very low concentrations of albumin are present intracellularly (Peters, 1996). Albumin returns from the extravascular space to the circulation via the lymphatic system, making $\sim 28$ "trips" in and out of the lymphatic system during its lifetime (Peters, 1996; Evans, 2002).

Upon secretion from hepatocytes, albumin enters the circulation and translocates to the extracellular space through the pores of sinusoidal or fenestrated endothelium in certain organs, such as the liver, pancreas, small intestine and bone marrow 


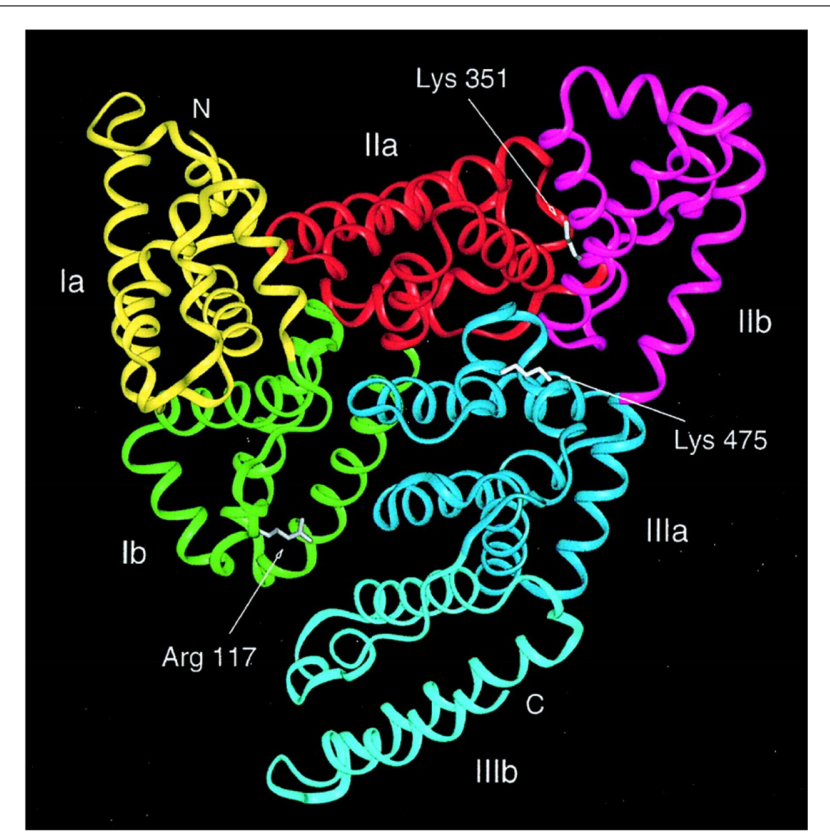

FIGURE 1 | Structure of human serum albumin consisting of three domains, each grouped into subdomains A and B (Subdomain la, yellow; lb, green; Ila, red; Ilb, magenta; Illa, blue; and Illb, cyan). Sugio et al. (1999) by permission of Oxford University Press.

(Peters, 1996). However, in organs where a continuous endothelium predominates, it is now believed that albumin can traverse the endothelium via active transcytotic mechanisms, including receptor-mediated mechanisms (e.g., albondin; see Section entitled "Cellular Albumin-Binding Proteins").

\section{ACCUMULATION OF ALBUMIN IN THE TUMOR INTERSTITIUM}

Solid tumors commonly possess an immature, highly permeable vasculature that is acted upon by vascular permeabilityenhancing factors (e.g., nitric oxide) (Carmeliet and Jain, 2000; Maeda et al., 2000; Greish, 2007; van der Veldt et al., 2008). However, despite this there is generally insufficient lymphatic drainage (Carmeliet and Jain, 2000; Maeda et al., 2000; Greish, 2007). This subsequently results in an accumulation of macromolecules $(>40 \mathrm{kDa})$ within the tumor interstitium, and this is known as the enhanced permeation and retention effect (Figure 2) (Maeda et al., 2000; Greish, 2007). Of interest, Matsumura and Maeda (1986) demonstrated that an intravenously injected Evans blue-albumin complex accumulated in sarcoma 180 tumors of ddY mice. The retention of albumin in tumors has since been observed in various experimental solid tumors (e.g., sarcoma, ovarian carcinoma, Novikof hepatoma, etc.) using radiolabeled- or dye-complexed serum albumin (Peterson and Appelgren, 1973; Sinn et al., 1990; Andersson et al., 1991; Schilling et al., 1992; Stehle et al., 1997; Wunder et al., 1997).

Additionally, a number of studies have proposed that tumors are a site of albumin catabolism (Hradec, 1958; Andersson et al., 1991; Schilling et al., 1992; Stehle et al., 1997). For instance, in

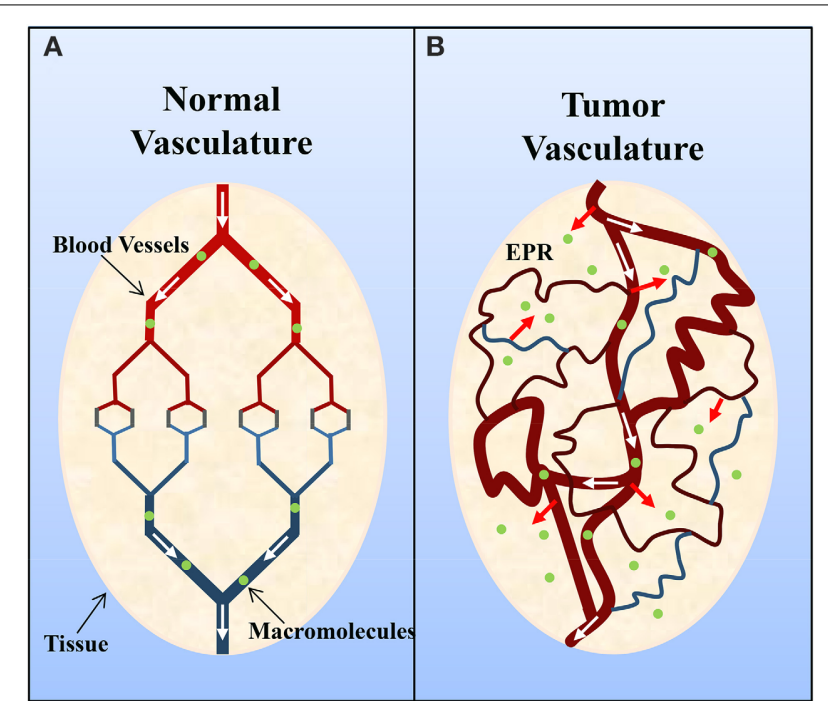

FIGURE 2 | Schematic representation of (A) normal and (B) tumor vasculature. Normal tissue is composed of mature, organized blood vessels, while tumor tissue consists of immature, leaky and tortuous vessels. The altered organization of tumor vasculature and disorganized lymphatic network results in vascular leakage and the accumulation of macromolecules (>40 kDa) within the interstitium and is known as the enhanced permeation and retention (EPR) effect. Adapted by permission from Macmillan Publishers Ltd: Nature Medicine (Jain, 2001), copyright (2001).

a mouse sarcoma model (C57/RL6J) injected with ${ }^{3} \mathrm{H}$-raffinoselabeled albumin, at least 2-3-fold greater levels of ${ }^{3} \mathrm{H}$ were observed in the lysosomes of tumors when compared with lysosomes of normal tissue (Andersson et al., 1991). Furthermore studies have demonstrated that albumin has a shorter half-life and a higher turnover in tumor-bearing mice, despite a compensatory increase in hepatic albumin synthesis, compared to non-tumor-bearing mice (Hradec, 1958). Hence, it has been suggested that tumors utilize albumin as a source of energy, by breaking down albumin into its component amino acids in lysosomes that are subsequently used by cancer cells for their accelerated growth (Stehle et al., 1997). Moreover, studies have suggested that the hypoalbuminiemia evident in cancer patients is a result of albumin catabolism by the tumor (Stehle et al., 1997).

Nevertheless, some of these earlier studies suffer from several experimental limitations. For instance, it is difficult to obtain pure lysosomal fractions and, thus, it is necessary to reproduce these studies and test the purity of fractions using well established membrane and organelle markers (Graham, 2002; Yamagishi et al., 2013). Additionally, several other in vivo factors may affect albumin degradation and catabolism (e.g., levels of corticosteroids) (Peters, 1996). Therefore, a clear-cut relationship has not been established and additional in vivo studies are necessary to support the intracellular distribution and catabolism of albumin by tumors.

More recently, Commisso et al. observed that cancer cells harboring endogenous oncogenic Ras mutations have increased levels of macropinocytosis in vitro and in vivo (Commisso et al., 2013). Moreover, it was demonstrated that FITC-labeled albumin was internalized through macropinocytosis and subsequently 
resulted in increased levels of glutamate and $\alpha$-ketoglutarate in oncogenic Ras-transformed cells (Commisso et al., 2013). Interestingly, the decrease in proliferation of oncogenic Rasexpressing cells after glutamine deprivation was shown to be rescued by extracellular albumin supplementation (Commisso et al., 2013). These findings suggest that macropinocytosis of albumin provides nutrients to sustain cancer cell proliferation (Commisso et al., 2013).

\section{CELLULAR ALBUMIN-BINDING PROTEINS}

Considering the importance of albumin, a number of putative albumin-binding proteins and receptors have been identified in various tissues and cell lines (Table 1), including kidney (Zhai et al., 2000; Amsellem et al., 2010), endothelium (Schnitzer and Bravo, 1993), fibroblasts (Porter et al., 1995), and tumor-cell surfaces (Fritzsche et al., 2004). Specifically, seven membrane-associated albumin-binding proteins have been discovered, namely: albondin/glycoprotein 60 (gp60) (Schnitzer et al., 1988), glycoprotein 18 (gp18) (Ghinea et al., 1988), glycoprotein 30 (gp30) (Ghinea et al., 1988), the neonatal Fc receptor (FcRn) (Roopenian and Akilesh, 2007), heterogeneous nuclear ribonucleoproteins (hnRNPs) (Fritzsche et al., 2004), calreticulin (Fritzsche et al., 2004), cubilin (Zhai et al., 2000; Amsellem et al., 2010), and megalin (Zhai et al., 2000; Amsellem et al., 2010). Moreover, a secreted albumin-binding protein known as secreted protein, acidic and rich in cysteine (SPARC) has been identified (Schnitzer and Oh, 1992). Considering their importance in albumin uptake by cells, each of these proteins are described in detail below.

\section{ALBONDIN/gp60}

Albondin (gp60) is a $60 \mathrm{kDa}$ glycoprotein that acts as an albumin receptor that is widely distributed, but is selectively expressed on the plasma membrane of continuous endothelium (except for the brain), where it operates to increase capillary permeability (Ghinea et al., 1988, 1989; Schnitzer et al., 1988; Schnitzer, 1992; Schnitzer and Oh, 1994; Tiruppathi et al., 1996). Albondin not only specifically binds native albumin, but also facilitates its internalization and subsequent transcytosis (Milici et al.,
1987; Schnitzer, 1992; Schnitzer and Oh, 1994; Tiruppathi et al., 1996).

It has been proposed that $\sim 50 \%$ of albumin leaves the capillary lumen via albondin, with the remainder traversing this barrier through intercellular junctions and/or fluid-phase mechanisms (Schnitzer, 1993; Schnitzer and Oh, 1994). Moreover, it has been demonstrated that the internalization of albondin occurs through a caveolin-dependent endocytotic process that results in transcytosis and does not appear to enter the degradative endosome-lysosome system (Schnitzer, 1993; Schnitzer and Bravo, 1993; Schnitzer et al., 1995; Tiruppathi et al., 1997; Iancu et al., 2011).

\section{gp18 AND gp30}

Both gp18 and gp30 avidly bind conformationally-modified albumin (i.e., gold-labeled albumin, formaldehyde- or maleicanhydride-treated albumin) and do not preferentially interact with native albumin, similarly to other known scavenger receptors (Ghinea et al., 1989; Schnitzer and Oh, 1992, 1994; Schnitzer et al., 1992; Schnitzer and Bravo, 1993). Unlike albondin, gp18 and gp30 are found on a variety of cells, such as macrophages and fibroblasts, and a range of endothelia (Schnitzer et al., 1992). Moreover, gp18 has been observed to be expressed in human MDA-MB-453 breast cancer cells (Wang et al., 1994). These scavenger receptors bind and direct modified albumins for degradation, perhaps as part of protein catabolism or as a protective pathway to remove altered, old, damaged or potentially deleterious albumins (Schnitzer, 1993; Schnitzer and Bravo, 1993). Albumin may be modified through oxidation, non-enzymatic glycation, maleylation, etc. as a result of normal aging or as a protective or pathological response (Schnitzer, 1993; Peters, 1996). Denatured or modified albumin is degraded faster and more efficiently than native albumin, suggesting that these alterations select albumin molecules for degradation (Peters, 1996).

\section{SPARC}

SPARC is also known as osteonectin and BM-40 and is secreted by several cell types (Brekken and Sage, 2001). Interestingly, SPARC

Table 1 | Localization of albumin-binding proteins and receptors.

\begin{tabular}{|c|c|c|}
\hline Protein/Receptor & Tissue & Substrate \\
\hline Albondin/gp60 & Continuous endothelium & Native albumin \\
\hline gp18 & Endothelium, macrophages, fibroblasts and MDA-MB-453 breast cancer cell surfaces & Modified-albumin \\
\hline gp30 & Endothelium, macrophages, fibroblasts and MDA-MB-453 breast cancer cell surfaces & Modified-albumin \\
\hline SPARC & $\begin{array}{l}\text { Endothelial cells, vascular smooth muscle cells, skeletal muscle, fibroblasts, testicular, ovarian, } \\
\text { pancreatic and a range of tumor cells }\end{array}$ & Native albumin \\
\hline hnRNPs & Human tumor cell lines: CEM T-cell leukemia cells, MCF-7 breast cancer cells and MV3 melanoma cells & Native albumin \\
\hline Calreticulin & Human tumor cell lines: CEM T-cell leukemia cells, MCF-7 breast cancer cells and MV3 melanoma cells & Native albumin \\
\hline FcRn & $\begin{array}{l}\text { Endothelium, antigen-presenting cells, gut, kidneys, lungs and the blood-brain-barrier (central nervous } \\
\text { system endothelium and choroid plexus) }\end{array}$ & Native albumin \\
\hline Cubilin & Kidney proximal tubule cells, absorptive intestinal cells, placenta, and visceral yolk-sac cells & $\begin{array}{l}\text { Native albumin and prob- } \\
\text { ably modified-albumin }\end{array}$ \\
\hline Megalin & $\begin{array}{l}\text { Kidney proximal tubule cells, absorptive intestinal cells, placenta, visceral yolk-sac cells, choroid } \\
\text { plexus, thyrocytes, ciliary epithelium, lungs, parathyroid, endometrium, oviduct, inner ear, and } \\
\text { epididymal epithelial cells }\end{array}$ & $\begin{array}{l}\text { Native albumin and prob- } \\
\text { ably modified-albumin }\end{array}$ \\
\hline
\end{tabular}


has been found to be highly expressed in malignant cells and stromal cells associated with neoplasia (Porter et al., 1995; Podhajcer et al., 2008). SPARC possesses albumin-binding properties and specifically interacts with native albumin in a similar way to albondin, but differing from 18 to gp30 that bind conformationally altered albumin (Schnitzer and Oh, 1992). Specifically, antiSPARC antibodies also recognize albondin, but not 18 or gp30, suggesting that SPARC and albondin share a native albuminbinding domain (Schnitzer and Oh, 1992). However, there is no evidence that SPARC mediates albumin uptake into tumors. It has been postulated that the ability of SPARC to bind albumin in the tumor interstitium enhances the accumulation of albuminbound drugs within the tumor space (Desai et al., 2008, 2009). Moreover, a preliminary clinical trial demonstrated that SPARC expression correlated with the response to paclitaxel-loaded albumin nanoparticle (nab-paclitaxel or Abraxane ${ }^{\circledR}$ ) treatment, with SPARC-positive patients having a better clinical outcome (Desai et al., 2009). However, conflicting data in a KPfC mouse model has challenged this hypothesis, as SPARC deficiency did not alter the intra-tumoral concentrations of Abraxane ${ }^{\circledR}$ (Neesse et al., 2014). Consequently, further studies are necessary to validate this hypothesis, including larger clinical trials involving a greater number of patients. Currently, a phase III study (NCT00785291), by the National Cancer Institute, is evaluating whether SPARC expression in serum predicts patient response to Abraxane ${ }^{\circledR}$, and this may further our understanding of the role of SPARC in albumin accumulation by tumors.

\section{hnRNPs AND CALRETICULIN}

Five different albumin-binding proteins have been identified from plasma membranes of human cancer cells lines (i.e., CCRF-CEM T-cell leukemia, MV3 melanoma and MCF7 breast carcinoma) (Fritzsche et al., 2004). Four of these proteins were identified as members of the hnRNP family, including hnRNP A2/B1, hnRNP $\mathrm{C} 1, \mathrm{hnRNP} \mathrm{A} 1$ and hnRNP A3, and the fifth protein was found to be calreticulin (Fritzsche et al., 2004). Calreticulin was first described as an endoplasmic reticulum chaperone and calcium signaling protein, but has since been shown to be involved in several cellular functions, including cell adhesion, modulation of platelet-collagen interactions (wound healing) and apoptosis (Mendlovic and Conconi, 2010). The functions of the hnRNP family are not well characterized. However, most members of the hnRNP family have been described as nuclear RNA-binding proteins involved in pre-mRNA processing, such as RNA splicing, export and stability (Chaudhury et al., 2010). Interestingly, hnRNPs have been proposed to play a role in carcinogenesis where their over-expression acts as biomarkers for the early detection of tumors (Han et al., 2013). The significance of these findings is currently unclear and it remains to be determined whether these proteins are involved in albumin-mediated uptake.

\section{FcRn}

FcRn is expressed in multiple cell-types and tissues, including antigen-presenting cells, vascular endothelium, gut, lungs, kidneys and the blood-brain barrier (BBB) (i.e., endothelium and choroid plexus) (Roopenian and Akilesh, 2007). This receptor protects albumin and IgG, from degradation by binding both proteins with high affinity only at a low $\mathrm{pH}(\mathrm{pH}<6.5)$ in acidic endosomes, preventing their degradation via the lysosomal pathway and returning them to the extracellular space ( $\mathrm{pH}$ 7.4) (Chaudhury et al., 2003; Ober et al., 2004; Anderson et al., 2006; Andersen et al., 2012). This consequently extends the half-life of serum albumin (Chaudhury et al., 2003; Anderson et al., 2006; Sarav et al., 2009). The role of this receptor in albumin uptake by tumors remains unclear.

\section{CUBILIN AND MEGALIN}

Cubilin is a multi-ligand receptor that is most recognized for its involvement in the intestinal uptake of the intrinsic factor vitamin $B_{12}$ complex (Seetharam et al., 1997). Moreover, cubilin has been shown to be involved in the endocytosis and transcellular transport of numerous ligands, including albumin (Birn et al., 2000). Cubilin is localized to absorptive intestinal cells, placenta, visceral yolk-sac cells and proximal tubules of kidneys (Christensen and Birn, 2002). Megalin is a large trans-membrane protein that has also been shown to bind albumin (Cui et al., 1996). This protein is more widely expressed than cubilin, being present in the choroid plexus, kidney proximal tubule cells, thyrocytes, etc. (Table 1) (Christensen and Birn, 2002).

Interestingly, megalin binds to cubilin with high affinity and it has been suggested that megalin contributes to the internalization of cubilin-ligand complexes as a co-receptor (Moestrup et al., 1998; Christensen and Birn, 2002). Moreover, cubilin also binds amnionless, a protein that is necessary for the expression of cubilin on the cell membrane (Amsellem et al., 2010). Cubilin, in conjunction with megalin, has an essential role in the uptake of albumin (i.e., reabsorption) by the proximal tubules of the kidneys (Zhai et al., 2000; Amsellem et al., 2010). Cubilin- and/or megalin-deficiency in mice and dogs was shown to cause a decrease in the uptake of albumin in the proximal tubule resulting in albuminuria (Birn et al., 2000; Amsellem et al., 2010). Additionally, patients with Imerslund-Gräsbeck syndrome, caused by a mutation in the cubilin gene, in general suffer from proteinurea, demonstrating the importance of cubilin in protein renal reabsorption (Grasbeck, 2006).

\section{ALBUMIN AS A DRUG CARRIER IN ONCOLOGY}

Considering the enhanced permeation and retention effect and the accumulation of albumin in the tumor interstitium, the development of albumin as a drug carrier is increasingly important to consider in terms of the targeted delivery of cancer therapy (Kratz, 2008, 2010). It has also been proposed that albumin carriers take advantage of the presence of albondin on the endothelium and SPARC in the tumor interstitium to increase the accumulation of drugs in the tumor space (Desai et al., 2009; Kratz, 2010). Various drug delivery systems with albumin have been developed including albumin nanoparticles, drug albumin conjugates, albumin-binding drug derivatives and prodrugs (for reviews see Kratz, 2008, 2010).

The development and market approval of the paclitaxelloaded albumin nanoparticle, nab-paclitaxel or Abraxane ${ }^{\circledR}$, was a major breakthrough in the field of albumin carrier development. Abraxane ${ }^{\circledR}$ was initially approved for clinical use in the United States in 2005 (Kudlowitz and Muggia, 2014). This albumin 
nanoparticle is indicated for the treatment of metastatic breast cancer, after failure of combination chemotherapy (Kudlowitz and Muggia, 2014). More recently, Abraxane ${ }^{\circledR}$ has also been described for the first-line treatment of patients with metastatic adenocarcinoma of the pancreas, in combination with gemcitabine, and patients with locally advanced or metastatic nonsmall cell lung carcinoma, in combination with carboplatin (Kudlowitz and Muggia, 2014). Abraxane ${ }^{\circledR}$ has a greater therapeutic index than paclitaxel alone, being administered at higher doses with less toxicity and more efficacy than traditional paclitaxel therapy (Gradishar et al., 2005; Socinski et al., 2012; Iwamoto, 2013). Abraxane ${ }^{\circledR}$ is currently still being further evaluated in clinical trials for other tumors, such as cancer of the bladder (NCT00583349) and multiple myeloma (NCT02075021).

Moreover, albumin-binding as a general strategy for improving the pharmacokinetics of drugs is also being assessed. Traditionally, the binding of a drug to albumin is believed to reduce the level of free drug available to exert its therapeutic activity (Lancon et al., 2004; Vuignier et al., 2010). However, studies have also demonstrated mechanisms by which albumin acts to effectively improve therapeutic use or reduce rapid clearance (Dennis et al., 2002; Merlot and Richardson, 2014). For instance, the experimental anti-cancer thiosemicarbazone, namely di2-pyridylketone 4,4-dimethyl-3-thiosemicarbazone (Dp44mT) (Merlot et al., 2013a), has been shown to be internalized by cancer cells via a putative carrier/receptor (Merlot et al., 2013b; Merlot and Richardson, 2014). Interestingly, the uptake, toxicity and apoptotic activity of Dp44mT is greatly enhanced in the presence of HSA (Merlot and Richardson, 2014). Considering Dp44mT targets lysosomes to induce apoptosis (Lovejoy et al., 2011), and that HSA potentially undergoes lysosomal catabolism in tumors (Andersson et al., 1991; Stehle et al., 1997), it can be hypothesized that HSA facilitates Dp44mT delivery to the lysosomes, enhancing its anti-cancer activity (Merlot and Richardson, 2014). Although studies are yet to identify the exact mechanism of the HSA-stimulated uptake process, albumin-binding may provide an advantage when generating tumor targeting agents and this requires further intense investigation.

\section{CONCLUSION}

Albumin is a versatile and captivating protein. In view of the large confinement of albumin within the vascular and interstitial space, the intracellular distribution of albumin has remained poorly characterized for many years. It may be possible that albumin, under specific conditions or during cellular stress, is taken up by normal cells and tumor cells at low and high levels, respectively, due to their metabolic rate. The exact role of some incompletely characterized albumin-binding proteins (i.e., hnRNPs and calreticulin) in mediating albumin uptake remains to be determined. However, the search and characterization of albumin-binding proteins, particularly in cancer cells, is of considerable interest in light of the development of albumin as an effective drug carrier to target tumors.

\section{ACKNOWLEDGMENTS}

Angelica M. Merlot is the recipient of an Early Career Research Grant from the University of Sydney. Des R. Richardson is the recipient of a National Health and Medical Research Council (NHMRC) Senior Principal Research Fellowship and Project Grants. Danuta S. Kalinowski is the recipient of a NHMRC Project Grant (1048972) and a Helen and Robert Ellis Fellowship from the Sydney Medical School Foundation of The University of Sydney.

\section{REFERENCES}

Amsellem, S., Gburek, J., Hamard, G., Nielsen, R., Willnow, T. E., Devuyst, O., et al. (2010). Cubilin is essential for albumin reabsorption in the renal proximal tubule. J. Am. Soc. Nephrol. 21, 1859-1867. doi: 10.1681/ASN.2010 050492

Andersen, J. T., Dalhus, B., Cameron, J., Daba, M. B., Plumridge, A., Evans, L., et al. (2012). Structure-based mutagenesis reveals the albumin-binding site of the neonatal Fc receptor. Nat. Commun. 3, 610. doi: 10.1038/ncomms1607

Anderson, C. L., Chaudhury, C., Kim, J., Bronson, C. L., Wani, M. A., and Mohanty, S. (2006). Perspective-FcRn transports albumin: relevance to immunology and medicine. Trends Immunol. 27, 343-348. doi: 10.1016/j.it.2006.05.004

Andersson, C., Iresjo, B. M., and Lundholm, K. (1991). Identification of tissue sites for increased albumin degradation in sarcoma-bearing mice. J. Surg. Res. 50, 156-162. doi: 10.1016/0022-4804(91)90240-M

Birn, H., Fyfe, J. C., Jacobsen, C., Mounier, F., Verroust, P. J., Orskov, H., et al. (2000). Cubilin is an albumin binding protein important for renal tubular albumin reabsorption. J. Clin. Invest. 105, 1353-1361. doi: 10.1172/ JCI8862

Brekken, R. A., and Sage, E. H. (2001). SPARC, a matricellular protein: at the crossroads of cell-matrix communication. Matrix Biol. 19, 816-827. doi: 10.1016/S0945-053X(00)00133-5

Carmeliet, P., and Jain, R. K. (2000). Angiogenesis in cancer and other diseases. Nature 407, 249-257. doi: 10.1038/35025220

Chaudhury, A., Chander, P., and Howe, P. H. (2010). Heterogeneous nuclear ribonucleoproteins (hnRNPs) in cellular processes: focus on hnRNP El's multifunctional regulatory roles. RNA 16, 1449-1462. doi: 10.1261/rna. 2254110

Chaudhury, C., Mehnaz, S., Robinson, J. M., Hayton, W. L., Pearl, D. K., Roopenian, D. C., et al. (2003). The major histocompatibility complex-related Fc receptor for IgG $(\mathrm{FcRn})$ binds albumin and prolongs its lifespan. J. Exp. Med. 197, 315-322. doi: 10.1084/jem.20021829

Christensen, E. I., and Birn, H. (2002). Megalin and cubilin: multifunctional endocytic receptors. Nat. Rev. Mol. Cell Biol. 3, 256-266. doi: 10.1038/nrm778

Commisso, C., Davidson, S. M., Soydaner-Azeloglu, R. G., Parker, S. J., Kamphorst, J. J., Hackett, S., et al. (2013). Macropinocytosis of protein is an amino acid supply route in Ras-transformed cells. Nature 497, 633-637. doi: 10.1038 /nature 12138

Cui, S., Verroust, P. J., Moestrup, S. K., and Christensen, E. I. (1996). Megalin/gp330 mediates uptake of albumin in renal proximal tubule. Am. J. Physiol. 271, F900-F907. doi: 0363-6127196

Dennis, M. S., Zhang, M., Meng, Y. G., Kadkhodayan, M., Kirchhofer, D., Combs, D., et al. (2002). Albumin binding as a general strategy for improving the pharmacokinetics of proteins. J. Biol. Chem. 277, 35035-35043. doi: 10.1074/jbc.M205854200

Desai, N., Trieu, V., Damascelli, B., and Soon-Shiong, P. (2009). SPARC expression correlates with tumor response to albumin-bound paclitaxel in head and neck cancer patients. Transl. Oncol. 2, 59-64. doi: 10.1593/tlo.09109

Desai, N. P., Trieu, V., Hwang, L. Y., Wu, R., Soon-Shiong, P., and Gradishar, W. J. (2008). Improved effectiveness of nanoparticle albumin-bound (nab) paclitaxel versus polysorbate-based docetaxel in multiple xenografts as a function of HER2 and SPARC status. Anticancer Drugs 19, 899-909. doi: 10.1097/CAD.0b013e32830f9046

Evans, T. W. (2002). Review article: albumin as a drug-biological effects of albumin unrelated to oncotic pressure. Aliment. Pharmacol. Ther. 16(Suppl. 5), 6-11. doi: 10.1046/j.1365-2036.2002.00190.x

Fritzsche, T., Schnolzer, M., Fiedler, S., Weigand, M., Wiessler, M., and Frei, E. (2004). Isolation and identification of heterogeneous nuclear ribonucleoproteins (hnRNP) from purified plasma membranes of human tumour cell lines as albumin-binding proteins. Biochem. Pharmacol. 67, 655-665. doi: 10.1016/j.bcp.2003.09.027 
Ghinea, N., Eskenasy, M., Simionescu, M., and Simionescu, N. (1989). Endothelial albumin binding proteins are membrane-associated components exposed on the cell surface. J. Biol. Chem. 264, 4755-4758.

Ghinea, N., Fixman, A., Alexandru, D., Popov, D., Hasu, M., Ghitescu, L., et al. (1988). Identification of albumin-binding proteins in capillary endothelial cells. J. Cell Biol. 107, 231-239. doi: 0021-9525/88/07/231/9

Gradishar, W. J., Tjulandin, S., Davidson, N., Shaw, H., Desai, N., Bhar, P., et al (2005). Phase III trial of nanoparticle albumin-bound paclitaxel compared with polyethylated castor oil-based paclitaxel in women with breast cancer. J. Clin. Oncol. 23, 7794-7803. doi: 10.1200/JCO.2005.04.937

Graham, J. M. (2002). Preparation of crude subcellular fractions by differential centrifugation. ScientificWorldJournal 2, 1638-1642. doi: 10.1100/tsw.2002.851

Grasbeck, R. (2006). Imerslund-Grasbeck syndrome (selective vitamin B(12) malabsorption with proteinuria). Orphanet. J. Rare Dis. 1:17. doi: 10.1186/17501172-1-17

Greish, K. (2007). Enhanced permeability and retention of macromolecular drugs in solid tumors: a royal gate for targeted anticancer nanomedicines. J. Drug Target. 15, 457-464. doi: 10.1080/10611860701539584

Han, N., Li, W., and Zhang, M. (2013). The function of the RNA-binding protein hnRNP in cancer metastasis. J. Cancer Res. Ther. 9(Suppl.), S129-S134. doi: 10.4103/0973-1482.122506

Hawkins, J. W., and Dugaiczyk, A. (1982). The human serum albumin gene: structure of a unique locus. Gene 19, 55-58. doi: 10.1016/0378-1119(82) 90188-3

He, X. M., and Carter, D. C. (1992). Atomic structure and chemistry of human serum albumin. Nature 358, 209-215. doi: 10.1038/358209a0

Hradec, J. (1958). Metabolism of serum albumin in tumour-bearing rats. Br. J. Cancer 12, 290-304. doi: 10.1038/bjc.1958.35

Iancu, C., Mocan, L., Bele, C., Orza, A. I., Tabaran, F. A., Catoi, C., et al. (2011). Enhanced laser thermal ablation for the in vitro treatment of liver cancer by specific delivery of multiwalled carbon nanotubes functionalized with human serum albumin. Int. J. Nanomed. 6, 129-141. doi: 10.2147/IJN.S15841

Iwamoto, T. (2013). Clinical application of drug delivery systems in cancer chemotherapy: review of the efficacy and side effects of approved drugs. Biol. Pharm. Bull. 36, 715-718. doi: 10.1248/bpb.b12-01102

Jain, R. K. (2001). Normalizing tumor vasculature with anti-angiogenic therapy: a new paradigm for combination therapy. Nat. Med. 7, 987-989. doi: 10.1038/nm 0901-987

Kragh-Hansen, U. (1981). Molecular aspects of ligand binding to serum albumin. Pharmacol. Rev. 33, 17-53. doi: 0031-6997/81/3301-0017

Kratz, F. (2008). Albumin as a drug carrier: design of prodrugs, drug conjugates and nanoparticles. J. Control. Release 132, 171-183. doi: 10.1016/j.jconrel.2008.05.010

Kratz, F. (2010). Albumin, a versatile carrier in oncology. Int. J. Clin. Pharmacol. Ther. 48, 453-455. doi: 10.5414/CPP48453

Kudlowitz, D., and Muggia, F. (2014). Nanoparticle albumin-bound paclitaxel (nab-paclitaxel): extending its indications. Expert Opin. Drug Saf. 13, 681-685. doi: 10.1517/14740338.2014.910193

Lancon, A., Delmas, D., Osman, H., Thenot, J. P., Jannin, B., and Latruffe, N. (2004). Human hepatic cell uptake of resveratrol: involvement of both passive diffusion and carrier-mediated process. Biochem. Biophys. Res. Comm. 316, 1132-1137. doi: 10.1016/j.bbrc.2004.02.164

Lovejoy, D. B., Jansson, P. J., Brunk, U. T., Wong, J., Ponka, P., and Richardson, D. R. (2011). Antitumor activity of metal-chelating compound Dp44mT is mediated by formation of a redox-active copper complex that accumulates in lysosomes. Cancer Res. 71, 5871-5880. doi: 10.1158/0008-5472.CAN-11-1218

Maeda, H., Wu, J., Sawa, T., Matsumura, Y., and Hori, K. (2000). Tumor vascular permeability and the EPR effect in macromolecular therapeutics: a review. J. Control. Release 65, 271-284. doi: 10.1016/S0168-3659(99)00248-5

Matsumura, Y., and Maeda, H. (1986). A new concept for macromolecular therapeutics in cancer chemotherapy: mechanism of tumoritropic accumulation of proteins and the antitumor agent smancs. Cancer Res. 46, 6387-6392.

Mendlovic, F., and Conconi, M. (2010). Calreticulin: a multifaceted protein. Nature Educ. 4,1 .

Merlot, A. M., Kalinowski, D. S., and Richardson, D. R. (2013a). Novel chelators for cancer treatment: where are we now? Antioxid. Redox Signal. 18, 973-1006. doi: 10.1089/ars.2012.4540

Merlot, A. M., Pantarat, N., Menezes, S. V., Sahni, S., Richardson, D. R., and Kalinowski, D. S. (2013b). Cellular uptake of the antitumor agent
Dp44mT occurs via a carrier/receptor-mediated mechanism. Mol. Pharmacol. 84, 911-924. doi: 10.1124/mol.113.088393

Merlot, A. M., and Richardson, D. R. (2014). Receptor recognition and lysosomal targeting to enhance cytotoxicity of novel anti-cancer agents that bind iron and copper. Vitam. Miner. 3:e125. doi: 10.4172/vms.1000e125

Milici, A. J., Watrous, N. E., Stukenbrok, H., and Palade, G. E. (1987). Transcytosis of albumin in capillary endothelium. J. Cell Biol. 105, 2603-2612. doi: 00219525/87/12/2603/10

Moestrup, S. K., Kozyraki, R., Kristiansen, M., Kaysen, J. H., Rasmussen, H. H., Brault, D., et al. (1998). The intrinsic factor-vitamin B12 receptor and target of teratogenic antibodies is a megalin-binding peripheral membrane protein with homology to developmental proteins. J. Biol. Chem. 273, 5235-5242. doi: 10.1074/jbc.273.9.5235

Neesse, A., Frese, K. K., Chan, D. S., Bapiro, T. E., Howat, W. J., Richards, F. M. et al. (2014). SPARC independent drug delivery and antitumour effects of nabpaclitaxel in genetically engineered mice. Gut 63, 974-983. doi: 10.1136/gutjnl2013-305559

Ober, R. J., Martinez, C., Lai, X., Zhou, J., and Ward, E. S. (2004). Exocytosis of IgG as mediated by the receptor, FcRn: an analysis at the single-molecule level. Proc. Natl. Acad. Sci. U.S.A. 101, 11076-11081. doi: 10.1073/pnas.040 2970101

Peters, T. (1996). All About Albumin: Biochemistry, Genetics and Medical Applications. San Diego, CA: Academic Press Limited.

Peterson, H. I., and Appelgren, K. L. (1973). Experimental studies on the uptake and rentention of labelled proteins in a rat tumour. Eur. J. Cancer 9, 543-547. doi: 10.1016/0014-2964(73)90142-4

Podhajcer, O. L., Benedetti, L. G., Girotti, M. R., Prada, F., Salvatierra, E., and Llera, A. S. (2008). The role of the matricellular protein SPARC in the dynamic interaction between the tumor and the host. Cancer Metastasis Rev. 27, 691-705. doi: 10.1007/s10555-008-9146-7

Porter, P. L., Sage, E. H., Lane, T. F., Funk, S. E., and Gown, A. M. (1995) Distribution of SPARC in normal and neoplastic human tissue. J. Histochem. Cytochem. 43, 791-800. doi: 10.1177/43.8.7622842

Roopenian, D. C., and Akilesh, S. (2007). FcRn: the neonatal Fc receptor comes of age. Nat. Rev. Immunol. 7, 715-725. doi: 10.1038/nri2155

Sarav, M., Wang, Y., Hack, B. K., Chang, A., Jensen, M., Bao, L., et al. (2009). Renal FcRn reclaims albumin but facilitates elimination of IgG. J. Am. Soc. Nephrol. 20, 1941-1952. doi: 10.1681/ASN.2008090976

Schilling, U., Friedrich, E. A., Sinn, H., Schrenk, H. H., Clorius, J. H., and MaierBorst, W. (1992). Design of compounds having enhanced tumour uptake, using serum albumin as a carrier-Part II. In vivo studies. Int. J. Rad. Appl. Instrum. B 19, 685-695. doi: 10.1016/0883-2897(92)90103-6

Schnitzer, J. E. (1992). gp60 is an albumin-binding glycoprotein expressed by continuous endothelium involved in albumin transcytosis. Am. J. Physiol. 262, H246-H254. doi: 0363-6135/92

Schnitzer, J. E. (1993). Update on the cellular and molecular basis of capillary permeability. Trends Cardiovasc. Med. 3, 124-130. doi: 10.1016/10501738(93)90012-U

Schnitzer, J. E., Allard, J., and Oh, P. (1995). NEM inhibits transcytosis, endocytosis, and capillary permeability: implication of caveolae fusion in endothelia. Am. J. Physiol. 268, H48-H55. doi: 0363-6135/95

Schnitzer, J. E., and Bravo, J. (1993). High affinity binding, endocytosis, and degradation of conformationally modified albumins. Potential role of gp30 and gp18 as novel scavenger receptors. J. Biol. Chem. 268, 7562-7570.

Schnitzer, J. E., Carley, W. W., and Palade, G. E. (1988). Albumin interacts specifically with a $60-\mathrm{kDa}$ microvascular endothelial glycoprotein. Proc. Natl. Acad. Sci. U.S.A. 85, 6773-6777. doi: 10.1073/pnas.85.18.6773

Schnitzer, J. E., and Oh, P. (1992). Antibodies to SPARC inhibit albumin binding to SPARC, gp60, and microvascular endothelium. Am. J. Physiol. 263, H1872-H1879.

Schnitzer, J. E., and Oh, P. (1994). Albondin-mediated capillary permeability to albumin. Differential role of receptors in endothelial transcytosis and endocytosis of native and modified albumins. J. Biol. Chem. 269, 6072-6082.

Schnitzer, J. E., Sung, A., Horvat, R., and Bravo, J. (1992). Preferential interaction of albumin-binding proteins, gp30 and gp18, with conformationally modified albumins. Presence in many cells and tissues with a possible role in catabolism. J. Biol. Chem. 267, 24544-24553.

Seetharam, B., Christensen, E. I., Moestrup, S. K., Hammond, T. G., and Verroust, P. J. (1997). Identification of rat yolk sac target protein of teratogenic antibodies, 
gp280, as intrinsic factor-cobalamin receptor. J. Clin. Invest. 99, 2317-2322. doi: 10.1172/JCI119411

Sinn, H., Schrenk, H. H., Friedrich, E. A., Schilling, U., and Maier-Borst, W. (1990). Design of compounds having an enhanced tumour uptake, using serum albumin as a carrier. Part I. Int. J. Rad. Appl. Instrum. B 17, 819-827. doi 10.1016/0883-2897(92)90103-6

Socinski, M. A., Bondarenko, I., Karaseva, N. A., Makhson, A. M., Vynnychenko, I., Okamoto, I., et al. (2012). Weekly nab-paclitaxel in combination with carboplatin versus solvent-based paclitaxel plus carboplatin as first-line therapy in patients with advanced non-small-cell lung cancer: final results of a phase III trial. J. Clin. Oncol. 30, 2055-2062. doi: 10.1200/JCO.2011. 39.5848

Stehle, G., Sinn, H., Wunder, A., Schrenk, H. H., Stewart, J. C., Hartung, G., et al. (1997). Plasma protein (albumin) catabolism by the tumor itself-implications for tumor metabolism and the genesis of cachexia. Crit. Rev. Oncol. Hematol. 26, 77-100. doi: 10.1016/S1040-8428(97)00015-2

Sudlow, G., Birkett, D. J., and Wade, D. N. (1976). Further characterization of specific drug binding sites on human serum albumin. Mol. Pharmacol. 12, 1052-1061.

Sugio, S., Kashima, A., Mochizuki, S., Noda, M., and Kobayashi, K. (1999). Crystal structure of human serum albumin at 2.5 A resolution. Protein Eng. 12, 439-446. doi: 10.1093/protein/12.6.439

Tiruppathi, C., Finnegan, A., and Malik, A. B. (1996). Isolation and characterization of a cell surface albumin-binding protein from vascular endothelial cells. Proc. Natl. Acad. Sci. U.S.A. 93, 250-254. doi: 10.1073/pnas.93.1.250

Tiruppathi, C., Song, W., Bergenfeldt, M., Sass, P., and Malik, A. B. (1997). Gp60 activation mediates albumin transcytosis in endothelial cells by tyrosine kinase-dependent pathway. J. Biol. Chem. 272, 25968-25975. doi: 10.1074/jbc.272.41.25968

van der Veldt, A. A., Luurtsema, G., Lubberink, M., Lammertsma, A. A., and Hendrikse, N. H. (2008). Individualized treatment planning in oncology: role of PET and radiolabelled anticancer drugs in predicting tumour resistance. Curr. Pharm. Des. 14, 2914-2931. doi: 10.2174/13816120878 6404344
Vuignier, K., Schappler, J., Veuthey, J. L., Carrupt, P. A., and Martel, S. (2010). Drugprotein binding: a critical review of analytical tools. Anal. Bioanal. Chem. 398, 53-66. doi: 10.1007/s00216-010-3737-1

Wang, J., Ueno, H., Masuko, T., and Hashimoto, Y. (1994). Binding of serum albumin on tumor cells and characterization of the albumin binding protein. J. Biochem. 115, 898-903.

Wunder, A., Stehle, G., Sinn, H., Schrenk, H., Hoffbiederbeck, D., Bader, F., et al. (1997). Enhanced albumin uptake by rat tumors. Int. J. Oncol. 11, 497-507. doi: 10.3892/ijo.11.3.497

Yamagishi, T., Sahni, S., Sharp, D. M., Arvind, A., Jansson, P. J., and Richardson, D. R. (2013). P-glycoprotein mediates drug resistance via a novel mechanism involving lysosomal sequestration. J. Biol. Chem. 288, 31761-31771. doi: 10.1074/jbc.M113.514091

Zhai, X. Y., Nielsen, R., Birn, H., Drumm, K., Mildenberger, S., Freudinger, R., et al. (2000). Cubilin- and megalin-mediated uptake of albumin in cultured proximal tubule cells of opossum kidney. Kidney Int. 58, 1523-1533. doi: 10.1046/j.1523-1755.2000.00314.x

Conflict of Interest Statement: The authors declare that the research was conducted in the absence of any commercial or financial relationships that could be construed as a potential conflict of interest.

Received: 02 July 2014; accepted: 23 July 2014; published online: 12 August 2014. Citation: Merlot AM, Kalinowski DS and Richardson DR (2014) Unraveling the mysteries of serum albumin—more than just a serum protein. Front. Physiol. 5:299. doi: 10.3389/fphys.2014.00299

This article was submitted to Integrative Physiology, a section of the journal Frontiers in Physiology.

Copyright (0) 2014 Merlot, Kalinowski and Richardson. This is an open-access article distributed under the terms of the Creative Commons Attribution License (CC BY). The use, distribution or reproduction in other forums is permitted, provided the original author(s) or licensor are credited and that the original publication in this journal is cited, in accordance with accepted academic practice. No use, distribution or reproduction is permitted which does not comply with these terms. 